\title{
Comment on 'New palaeomagnetic result from Vendian red sediments in Cisbaikalia and the problem of the relationship of Siberia and Laurentia in the Vendian' by S. A. Pisarevsky, R. A. Komissarova and A. N. Khramov
}

\author{
J. G. Meert ${ }^{1,2}$ and R. Van der Voo ${ }^{3}$ \\ ${ }^{1}$ Norwegian Geological Survey, Leiv Eirikssons vei 39, 7491 Trondheim, Norway. E-mail: joe.meert@ngu.no \\ ${ }^{2}$ Indiana State University, Department of Earth Sciences, Palaeomagnetics Laboratory, Terre Haute, IN 47809, USA \\ ${ }^{3}$ University of Michigan, Department of Geological Sciences, 2534 CC Little Building, Ann Arbor, MI 49109, USA
}

Accepted 2000 December 20. Received in original form 2000 September 12

\section{INTRODUCTION}

Pisarevsky et al. (2000) document a poorly dated pole from Vendian-age sedimentary rocks in Siberia and argue for a lowlatitude position of both Laurentia and Siberia during the interval from 650 to $550 \mathrm{Ma}$. Their argument is based, at least in part, on a reinterpretation of palaeomagnetic poles from Laurentia because previous studies (e.g. Symons \& Chiasson 1991; Meert et al. 1994; Torsvik et al. 1996) argued for a high latitude position for Laurentia beginning at $580 \mathrm{Ma}$ (perhaps earlier). The new data provided by Pisarevsky et al. (2000) are a welcome addition to the Siberian palaeomagnetic database; however, given the broad age range of their result, we feel that the authors over-interpret the extant data in an effort to rescue a controversial positioning of Siberia against the northern margin of Laurentia (Sears \& Price 2000; Pelechaty 1996; Hoffman 1991; Dalziel 1997; Condie \& Rosen 1994; Frost et al. 1998). Therefore, we wish to address the following points in the manuscript that we feel are contentious:

(1) low palaeolatitude position of Laurentia between 580 and $565 \mathrm{Ma}$;

(2) palaeogeographic implications of their proposed fit;

(3) position of Siberia against northern Laurentia.

\section{LATITUDE OF LAURENTIA IN THE LATEST NEOPROTEROZOIC}

Symons \& Chiasson (1991) argue convincingly that palaeomagnetic data from the Callander Complex indicate Laurentia occupied high latitudes during the latest Neoproterozoic (575 Ma). Their palaeomagnetic study is well documented and, as noted by Pisarevsky et al. (2000), contains a dual-polarity magnetization supported by a positive baked contact test. Pisarevsky et al. (2000) dismiss this pole with little explanation. Meert et al. (1994) presented data from the 564-570 Ma Catoctin volcanics in Virginia that also support a high latitude position for Laurentia at that time. We feel that the Catoctin pole was misinterpreted by Pisarevsky et al. (2000) in an effort to 'rescue' Laurentia to low latitudes and maintain an already tenuous link to Siberia into the Cambrian (similar to Pelechaty 1996).
Pisarevsky et al. (2000) ignore several points related to the argument favouring a primary magnetization for the Catoctin 'A' component (Meert et al. 1994) arguing instead that the Catoctin ' $\mathrm{B}$ ' component is primary. It is therefore useful to review the complete arguments made by Meert et al. (1994) for the primary 'A' remanence. Pisarevsky et al. (2000) correctly point out that the fold test for the 'B' component is of higher significance than the 'A' component. Folding of the Catoctin volcanic rocks occurred during Taconic deformation between 450 and $470 \mathrm{Ma}$, so the positive fold test constrains the age of magnetization of both the ' $\mathrm{B}$ ' and ' $\mathrm{A}$ ' components to older than 450-470 Ma. We concluded (Meert et al. 1994) that the 'less-positive' fold test in the A-component was due to the limited number of sites investigated. Indeed, it is useful to show the stepwise fold test for the A-component (Fig. 1a). The directional improvement upon tilt-correction is obvious from the graph, albeit significant only at the 92 per cent confidence level. The presence of reversals, in the absence of additional data, merely suggests that the magnetization in the rocks spanned at least one interval of field reversal. Both the ' $A$ ' and ' $\mathrm{B}$ ' magnetizations are dual-polarity. On the basis of these two arguments, Pisarevsky chose the 'B' component over the 'A' component to represent the primary magnetization.

Our conclusion regarding the primary nature of the A component went beyond that described by Pisarevsky et al. (2000). Specifically, we documented a baked contact test for a Catoctin feeder dike intrusive into the Grenvillian-age Pedlar granite at Site 8. Although, our baked contact test was not a 'classic' baked contact test due to the limited outcrop at the site, we feel that it provided additional compelling evidence for primary nature of the A-magnetization. The other rationale for choosing the A component as primary was based on the fact that the B component matched a well-known younger direction of magnetization (Late Cambrian age, Fig. 1b; Torsvik et al. 1996). Pisarevsky et al. (2000) rejected this argument citing the fact that 700-800 Ma poles are also similar to the Cambrian directions and yet are still considered primary. We find this argument weak as many of the studies from these older (700-800 Ma) rocks have palaeomagnetic tests that demonstrate their primary nature while the ' $\mathrm{B}$ ' Catoctin pole does not. The last point is that the A component of magnetization matches no known 


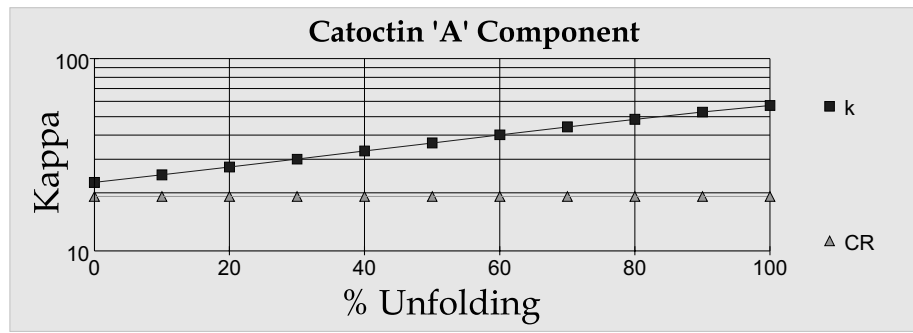

(a)
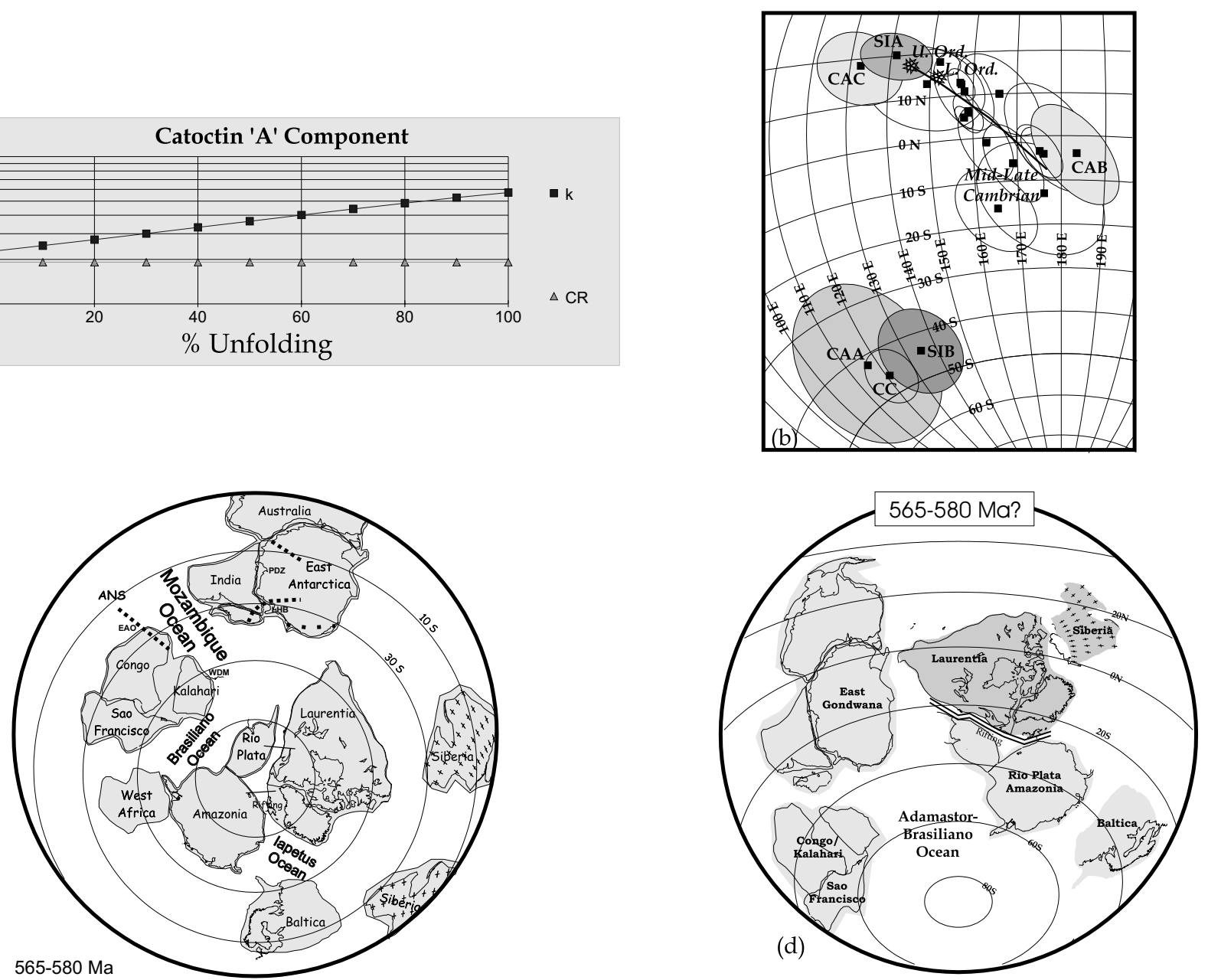

(c)

Figure 1. (a) Stepwise unfolding graph for the Catoctin 'A' component that shows the increased grouping of directions upon unfolding. (b) Apparent polar wander path for Laurentia showing the poles discussed in the paper. Light shading represents the poles from the Catoctin study and darker shading represents those from the Sept-Îles study. Pisarevsky et al. (2000) argue that the Catoctin 'B' pole (CAB) and Sept-Îles 'A' (SIA) are primary and date to $565 \mathrm{Ma}$, whereas Meert et al. (1994) argue that the Catoctin 'A' (CAA) and Sept-Îles 'B' (SIB) poles are primary. CC represents the 575 Ma Callander Complex pole of Symons \& Chiasson (1991). (c) 565-580 Ma reconstruction based on palaeomagnetic poles described in previous studies (see text for details) and the high latitude option for Laurentia. We position Siberia using the palaeomagnetic pole of Pisarevsky et al. (2000), but choose the opposite polarity for their pole. (d) Alternative reconstruction at 565-580 Ma using the Catoctin 'B' pole for Laurentia following the suggestion of Pisarevsky et al. (2000).

younger poles from Laurentia, is significantly different than the present Earth's field in Virginia and falls near a similar age pole in Laurentia with an unambiguous primary magnetization (the Callander Complex pole, Fig. 1b). We mostly agree with Pisarevsky et al. (2000) regarding the Sept-Îles and Long Range poles. We do wish to note one important point regarding the interpretation of the Sept-Îles pole that was not discussed by Pisarevsky et al. (2000). The age of the Sept-Îles is now well established by U-Pb dating at $565 \pm 4 \mathrm{Ma}$ (Higgins \& van Breeman 1998). The age overlaps with ages from the Catoctin volcanic province and therefore, primary poles from both these units should overlap. Pisarevsky et al. (2000) argue that both the Catoctin B pole and the Sept-Îles A pole are primary and date to $\sim 565 \mathrm{Ma}$. Fig. 1 (b) shows that the Sept-Îles A pole falls some $45^{\circ}$ from the Catoctin B pole. Perhaps more importantly, the Sept-îles A pole falls very close to Ordovician poles from North America and the Catoctin C pole that is clearly not primary (Fig. 1b, Symons \& Chiasson 1991; Meert et al. 1994; Tanczyk et al. 1987; Torsvik et al. 1996). In contrast, the Sept-Îles B pole (corrected for minor tilt as in Symons \& Chiasson 1991) is nearly identical to the Catoctin A pole and suggests to us that both magnetizations are the same age. We therefore maintain that the evidence favouring a high-latitude position for Laurentia based on palaeomagnetic data is strong as both the Callander Complex and Catoctin-A magnetizations cannot be dismissed as readily as Pisarevsky et al. (2000) maintain.

\section{GLOBAL IMPLICATIONS}

Although Pisarevsky et al. (2000) argued about the primary nature of the magnetizations found in both the Callander and Catoctin rocks, they failed to address some of the tectonic 
implications of their proposal. Indeed, we argue that the palaeogeographic implications of their arguments provide a strong rationale for rejecting the low-latitude position for Laurentia. Fig. 1(c) shows a reconstruction for the late Neoproterozoic $(580 \mathrm{Ma})$ based on palaeomagnetic data described elsewhere (Meert \& Van der Voo 1997; Torsvik et al. 1996; Meert \& Van der Voo 1996; Kempf et al. 2000). Although the assembly of greater Gondwana was diachronous, most agree that all cratons were in close proximity by 550-530 Ma (Kroner et al. 2000; Meert \& Van der Voo 1997. Trompette 1997; Torsvik et al. 1996). Trompette (1997) and Kroner et al. (2000) note collisional events between the Congo-Sao Francisco craton and (a) the Amazonia-Rio Plata cratons and (b) the elements of East Gondwana during the interval during the interval from 650 to $530 \mathrm{Ma}$. Fig. 1(d) shows an alternative reconstruction based on the premise of Pisarevsky et al. (2000) using a lowlatitude choice for Laurentia. Except in rare cases, palaeomagnetic data yield a degree of freedom in moving cratons along lines of longitude. Therefore, these reconstructions are flexible in the sense that the relative longitudinal distances between cratons are arbitrary. We merely attempt to reconstruct the globe in a manner consistent with the geological data. Trompette (1997) argues that the Congo-Sao Francisco, Kalahari and Rio Plata cratons had already collided by $c$. $600 \mathrm{Ma}$, an argument that is difficult to reconcile with the reconstruction in Fig. 1d (based on the Pisarevsky et al. 2000 model). In contrast, there is no space or orientation conflict in Fig. 1(c) using the high-latitude option for Laurentia. Furthermore, the proximity of the cratons (Fig. 1c) is consistent with proposed orogenic events in regions of the Mozambique Belt and also closure of the Braziliano Ocean during the interval from 600 to $550 \mathrm{Ma}$. We make the crucial assumption that rifting along the eastern margin of Laurentia does not commence until sometime post$575 \mathrm{Ma}$ allowing us to position the South American cratons alongside eastern Laurentia. The exact timing of the rift to drift transition is debated (Meert \& Van der Voo 1997; Dalziel 1997; Torsvik et al. 1996; Cawood et al. 2000) but it is difficult to argue on geological grounds for separation prior to $575 \mathrm{Ma}$.

\section{POSITION OF THE SIBERIAN CR A T ON}

Although Pisarevsky et al. (2000) and others (see Ernst et al. 2000) have argued for a reconstruction of Siberia against the northern margin of Laurentia, both the position and orientation are contentious (Sears \& Price 2000). Interestingly, there is not a single unequivocal palaeomagnetic case for placing Siberia against northern Laurentia and the geological arguments for such a position are equally arguable (Sears \& Price 2000; Frost et al. 1998; Hoffman 1991; Dalziel 1997; Pelechaty 1996; Condie \& Rosen 1994). Despite the disagreement over the position and orientation of Siberia, most maintain that the LaurentiaSiberia connection was valid from Mesoproterozoic time until Vendian/Early Cambrian separation. For example, Ernst et al. (2000) present data from the Kuonamka dikes at $1503 \pm 5 \mathrm{Ma}$ and argued that they are compatible with the position favoured by Dalziel (1997) and Pelechaty (1996); however, the comparison was made using much younger palaeomagnetic poles from Laurentia (<1450 Ma). In addition, the large error $\left(28^{\circ}\right)$ associated with the Kuonamka dike pole allows for the possibility of a fit against western Laurentia as favoured by
Sears \& Price (2000). Late Mesoproterozoic data from Siberia (Gallet et al. 2000) are equally contentious as they argue that a Siberian connection is possible against northern Laurentia, but the orientation of Siberia in their study (e.g. Rainbird et al. 1998 ) is quite different from that proposed by either Pelechaty (1996) or Pisarevsky et al. (2000). It is important to point out that all of these palaeomagnetic comparisons are made by selecting a polarity choice for the palaeomagnetic poles that minimizes the distance between the two cratons. Interestingly, the azimuthal orientation of Laurentia for much of the Neoproterozoic is such that Siberia can (within error) also be placed in a variety of orientations against the western margin of Laurentia (similar to Sears \& Price 2000). We therefore feel that Pisarevsky et al.'s (2000) attempt to rescue a particular reconstruction by rejecting two palaeomagnetic studies that support a high latitude position for Laurentia is without merit and the high palaeolatitude position for Laurentia between 580 and $565 \mathrm{Ma}$ is preferred.

\section{REFERENCES}

Cawood, P.A., McCausland, P.J.A. \& Dunning, G.R., 2000. Opening Iapetus: constraints from the Laurentia margin in Newfoundland, Bull. geol. Soc. Am., 113, 443-453.

Condie, K.C. \& Rosen, O.M., 1994. Laurentia-Siberia connection revisited, Geology, 22, 168-170.

Dalziel, I.W.D., 1997. Neoproterozoic-Paleozoic geography and tectonics: review, hypothesis and environmental speculation, Bull. geol. Soc. Am., 109, 16-42.

Ernst, R.E., Buchan, K.L., Hamilton, M.A., Okrugin, A.V. \& Tomshin, M.D., 2000. Integrated paleomagnetism and U-Pb geochronology of Mafic dikes of the Eastern Anabar shield region, Siberia: Implications for Mesoproterozoic paleolatitude of Siberia and comparison with Laurentia, J. Geol., 108, 381-401.

Frost, B.R., Avchenko, O.V., Chamberlin, K.R. \& Geldsetzer, H.H.J., 1998. Evidence for extensive Proterozoic remobilization of the Aldan shield and implications for Proterozoic plate tectonic reconstructions of Siberia and Laurentia, Precamb. Res., 89, 1-23.

Gallet, Y., Pavlov, V.E., Semikhatov, M.A. \& Petrov, P.Yu., 2000. Late Mesoproterozoic magnetostratigraphic results from Siberia: Paleogeographic implications and magnetic field behavior, J. geophys. Res., 105 (B7), 16 481-16 500.

Higgins, M.D. \& van Breeman, O., 1998. The age of the Sept-Îles layered mafic intrusion, Canada: implications for the late Neoproterozoic/Cambrian history of southeastern Canada, J. Geol., 106, 421-432.

Hoffman, P.F., 1991. Did the breakout of Laurentia turn Gondwanaland inside out?, Science, 252, 1409-1412.

Kempf, O., Kellerhalls, P., Lowrie, W. \& Matter, A., 2000. Paleomagnetic directions in Precambrian/Cambrian glaciomarine sediments of the Mirbat sandstone formation, Oman, Earth planet. Sci. Lett., 175, 181-190.

Kroner, A., Hegner, E., Collins, A., Windley, B.F., Brewer, T.S., Razakamanana, T. \& Pidgeon, R.T., 2000. Age and magmatic history of the Antananarivo block, central Madagascar, as derived from zircon geochronology and $\mathrm{Nd}$ isotopic systematics, Am. J. Sci., 300, 251-288.

Meert, J.G. \& Van der Voo, R., 1996. Paleomagnetic and ${ }^{40} \mathrm{Ar} /{ }^{39} \mathrm{Ar}$ study of the Sinyai dolerite, Kenya: Implications for Gondwana assembly, J. Geol., 104, 131-142.

Meert, J.G. \& Van der Voo, R., 1997. The assembly of Gondwana 800-550 Ma, J. Geodyn., 23, 223-235.

Meert, J.G., Van der Voo, R. \& Payne, T., 1994. Paleomagnetism of the Catoctin volcanic province: a new Vendian-Cambrian apparent polar wander path for North America, J. geophys. Res., 99 (B3), 4625-4641. 
Pelechaty, S.M., 1996. Stratigraphic evidence for the Siberia-Laurentia connection and Early Cambrian rifting, Geology, 24, 719-722.

Pisarevsky, S.A., Komissarova, R.A. \& Khramov, A.N., 2000. New paleomagnetic result from Vendian red sediments in Cisbaikalia and the problem of the relationship of Siberia and Laurentia in the Vendian, Geophys. J. Int., 140, 598-610.

Rainbird, R.H., Stern, R.A., Khudoley, A.K., Kropachev, A.P., Heamon, L.M. \& Sukhorukov, V.I., 1998. U-Pb geochronology of Riphean sandstone and gabbro from southeast Siberia and its bearing on the Laurentia-Siberia connection, Earth planet. Sci. Lett., 164, 409-420.

Sears, J.W. \& Price, R.A., 2000. New look at the Siberian connection: No SWEAT, Geology, 28, 423-426.
Symons, D.T.A. \& Chiasson, A.D., 1991. Paleomagnetism of the Callander Complex and the Cambrian apparent polar wander path for North America, Can. J. Earth Sci., 28, 355-363.

Tanczyk, E.I., Lapointe, P., Morris, W.A. \& Schmidt, P.W., 1987. A paleomagnetic study of the layered mafic intrusions at Sept-Iles, Quebec, Can. J. Earth Sci., 24, 1431-1438.

Torsvik, T.H., Smethurst, M.A., Meert, J.G., Van der Voo, R., McKerrow, W.S., Sturt, B.A., Brasier, M.D. \& Walderhaug, H.J., 1996. Continental breakup and collision in the Neoproterozoic and Paleozoic-A tale of Baltica and Laurentia, Earth Sci. Rev., 40, 229-258.

Trompette, R., 1997. Neoproterozoic ( $600 \mathrm{Ma})$ aggregation of Western Gondwana: a tentative scenario, Precamb. Res., 82, 101112. 